\title{
Agronomy, Utilization and Economics of Indigenous Vegetables in West Java, Indonesia
}

\author{
Edi Santosa $^{1,2^{*}}$, Utami Prawati ${ }^{1}$, Sobir ${ }^{1,2}$, Yoko Mine ${ }^{3}$ and Nobuo Sugiyama ${ }^{3}$ \\ Diterima 04 Agustus 2015/Disetujui 09 November 2015
}

\begin{abstract}
Indigenous vegetables have become popular in recent Indonesian diet, but agronomic and economic studies on these crops are limited. The objective of this research was to investigate the cultural technique of indigenous vegetables, their uses and economic importance in West Java, Indonesia. Initial market observation was conducted in Bogor to determine the economic value of indigenous vegetables. In depth observations of the indigenous vegetables and interviews with merchants, farmers and consumers were conducted in three districts, i.e., Bogor, Cianjur and Tasikmalaya, focusing on four indigenous vegetables familiar to local people, i.e., genjer (Limnocharis flava (L.) Buchenau), kenikir (Cosmos caudatus Kunth.), leunca (Solanum americanum Miller) and poh-pohan (Pilea melastomoides (Poir.) Wedd.). This study showed that indigenous vegetables have been produced in extensive and semi-intensive cultivations and are sold in local markets daily, although local people do not consume them frequently. Indigenous vegetables held a market share of less than 5\% at local markets, and accounted for less than 10\% in household vegetable consumption. The reasons for consumers to choose indigenous vegetables were familiarity to these crops, moderate prices, family members' preference, availability and ease of preparation. Generally, younger family members ( $<30$ years old) bought indigenous vegetables less frequently than older ones( $>30$ years old), possibly due to lack of information on its use, unfamiliar flavor and high availability of other commercial vegetables commonly grown worldwide.
\end{abstract}

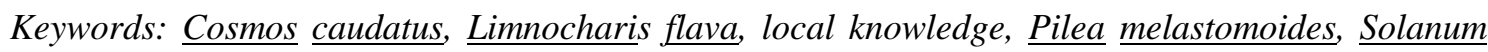
$\underline{\text { americanum }}$

\begin{abstract}
ABSTRAK
Popularitas sayuran indigenus terus meningkat di Indonesia, namun studi agronomi dan ekonominya masih terbatas. Penelitian bertujuan mengkaji budidaya, pemanfaatan dan nilai ekonomis sayuran indigenus di Jawa Barat, Indonesia. Penelitian pendahuluan dilakukan di pasar di wilayah Bogor. Penelitian mendalam dilakukan dengan mewawancarai pedagang, petani dan konsumen, serta mengamati di lahan petani di tiga kabupaten yakni Bogor, Cianjur dan Tasikmalaya untuk empat sayuran indigenus utama yakni genjer (Limnocharis flava (L.) Buchenau), kenikir (Cosmos caudatus Kunth.), leunca (Solanum americanum Miller) dan poh-pohan (Pilea melastomoides (Poir.) Wedd.). Studi menunjukkan bahwa sayuran indigenus diproduksi secara intensif dan semi intensif, serta dijual di pasar setiap hari, walaupun penduduk setempat tidak mengkonsumsi secara teratur. Sayuran indigenus mengisi celung pasar kurang dari 5\% dan memenuhi kurang dari 10\% kebutuhan sayuran rumah tangga. Konsumen memilih sayuran indigenus karena sudah terbiasa mengkonsumsi, harga terjangkau, disukai anggota keluarga, ketersediaan dan kemudahan mengolah. Secara umum, anggota keluarga muda (usia < 30 tahun) lebih jarang membeli sayuran indigenus dibanding yang lebih tua (usia > 30 tahun), kemungkinan disebabkan keterbatasan informasi nilai guna, adanya aroma asing, dan ketersediaan sayuran lain.
\end{abstract}

Kata kunci: Cosmos caudatus, Limnocharis flava, pengetahuan lokal, Pilea melastomoides, Solanum americanum

\footnotetext{
${ }^{1}$ Departemen Agronomi dan Hortikultura, Fakultas Pertanian, Institut Pertanian Bogor (Bogor Agricultural University), J1. Meranti Kampus Darmaga, Bogor 16680 Indonesia. Telp.\&Faks. 62-251-8629353.

${ }^{2}$ Center for Horticulture Studies, Bogor Agricultural University. J1 Pajajaran Kampus IPB Baranangsiang Bogor 16144, Indonesia.

${ }^{3}$ Faculty of Agriculture, Tokyo University of Agriculture, Funako, Atsugi, Kanagawa243-0034, Japan

email: edisang@gmail.com. (*corresponding author)
} 


\section{INTRODUCTION}

Before 2000 indigenous vegetables such as genjer (Limnocharis flava (L.) Buchenau), kenikir (Cosmos caudatus Kunth.), leunca (Solanum americanum Miller), poh-pohan (Pilea melastomoides (Poir.) Wedd.), young leaves of papaya (Carica papaya) and cashew (Anacardium occidentale) were only consumed in local areas in Java, Indonesia. However, the demand for indigenous vegetables is increasing significantly with the development of ethnic restaurants mainly Javanese and Sundanese restaurants, including street vendors/restaurants (warung kaki lima) in most big cities all over Indonesia, which resulted in the demands for agronomic and nutritional studies on indigenous vegetables.

Indigenous vegetables are usually defined as native or traditional vegetables (Kusmana and Suryadi, 2004) including introduced species that have evolved over a long period (Engle and Faustino, 2007). They are offered at an affordable price and have a distinct flavor, thus contributing greatly to farmers' economy, diet and social relations.

Among ethnic groups in Indonesia, Sundanese people living in West Java prepare indigenous vegetables as raw vegetables, pickles and stir-fried vegetables; indigenous vegetables are essential ingredients for various traditional dishes such as asinan (salty pickles), karedok (salad with peanut source), lalaban (raw vegetables with chili paste), pecel (peanut sauce for vegetables, catfish and chicken, etc.). Putrasamedja (2003) identified 111 indigenous vegetables in Indonesia, some of which had a variety of medicinal properties; katuk leaves (Sauropus androgynus (L.) Merr.) is believed to stimulate breast milk production, whereas leunca and takokak (Solanum torvum Sw.) are effective as a contraceptive.

Although, there are no statistical data of production and demands for indigenous vegetables, genjer (Limnocharitaceae), kenikir (Compositeae), leunca (Solanaceae) and pohpohan (Urticaceae) are popular to people in big cities in Java, Sumatra, Bali and Kalimantan Islands. Those vegetables provide protein, fat, carbohydrate, fibers and minerals such as $\mathrm{Ca}$ and $\mathrm{Fe}$ (Van den Bergh, 1994a,b). Genjer, kenikir and leunca have high vitamin A, $B_{1}$ and C content (Van den Bergh, 1994a,b; Siemonsma and Jansen, 1994; Hassan et al.,
2012). Kenikir also contains antioxidant (Andarwulan et al., 2010; Hassan et al., 2012), and essential oil (Van den Bergh, 1994a) which is reported to improve appetite. According Fuzzati et al. (1995), kenikir is native to tropical regions of the Americas and has been naturalized in Java.

Our knowledge about cultural practices and utilization of indigenous vegetables is scarce. Therefore, we examined how four most familiar indigenous vegetables are grown and harvested by farmers, traded in markets by merchants, and prepared by local people in West Java.

\section{MATERIALS AND METHODS}

Research was conducted in three districts, i.e., Bogor, Cianjur and Tasikmalaya, West Java, Indonesia during the rainy season from December 2010 to April 2011. Initially, all indigenous vegetables available in 14 Bogor markets (traditional and modern markets) were surveyed and evaluated, resulted in 30 species of indigenous vegetables. Twelve out of 30 indigenous vegetables were found in all markets. Preliminary evaluation on the 12 indigenous vegetables were conducted based on the availability in markets, volumes of sales, farmers' profitability of the cultivation and consumption frequency through interviews with merchants, farmers and consumers. We concluded four species, i.e., kenikir, genjer, leunca and poh-pohan as the most common and profitable in the markets, and as special cuisine in most Sundanese restaurants.

Further assessment was carried out following the distribution channel of vegetables from consumers in the markets to farmers. Two traditional markets, i.e., Pasar Bogor and Pasar Anyar in Bogor Districts, were selected based on easiness to access, large volume of sales, and rapid turnover of the vegetables. Interview was conducted with 14 merchants and their suppliers, each 7 merchants in Pasar Bogor and Pasar Anyar regarding vegetable availability, quantity, sales and origin. Pasar Bogor (Bogor Market) was considered as one of the largest vegetable markets in West Java, except for Jakarta markets. In this market, vegetables came from surrounding districts including Bandung, 
Sumedang, Sukabumi, Tasikmalaya and Cianjur Districts.

Of 10 production areas (villages) identified by interview with merchants (and suppliers) in the particular markets, we selected four villages which have been regularly supplied one or more of these indigenous vegetables, i.e., Sukaharja - Ciapus and Ciampea villages (Bogor District), Pasir Sarongge village (Cianjur District) and Citalahab village (Tasikmalaya District) located at an altitude of $300 \mathrm{~m}, 200 \mathrm{~m}, 1,200$ $\mathrm{m}$ and $700 \mathrm{~m}$ above sea level, respectively. In each village, we interviewed 20 to 25 female consumers, 2 to 3 local merchants (suppliers) and 7 to 10 large farmers. Only land owner were considered in this study, therefore, the number of farmers interviewed varied among sites. Female consumers were selected as they would decide which foods to buy. The consumers' age ranged from 20 to 57 years, education background varied from elementary school to university graduates, and level of monthly income range from 0.4 to 7.0 million rupiah (average 2.3 million rupiah).

In each village, cultivation method, growing area, handling and sales amount of indigenous vegetables, were investigated. To determine the vegetables productivity, we established a plot $(5 \mathrm{~m} \times 5 \mathrm{~m})$ in each village and requested one farmer to manage in each locations of study. Kenikir and leunca were cultivated in Ciampea (Bogor), Sukaharja Ciapus (Bogor) and Pasir Sarongge (Cianjur), while genjer and poh-pohan were grown in Ciampea (Bogor), Pasir Sarongge (Cianjur) and Citalahab (Tasikmalaya) villages. No farmers in Citalahab village (Tasikmalaya) were familiar with kenikir and leunca and Sukaharja - Ciapus (Bogor) for genjer and poh-pohan, therefore, no agronomic data were collected from those villages. Planting density and harvesting time were conformable to local farmers' standard of cultivation, and 10 plants were monitored regularly every 2 weeks. Oxalate crystals were observed by squeezing leaf/fruit and observed under microscope of 400x magnification and categorized as "+" indicates that druses of oxalate crystals are visible and "- " as not visible or absent. Data were analyzed using ANOVA and a Student's t-test was used to assess statistical significance of differences between means.

\section{RESULTS AND DISCUSSION}

\section{Culture Techniques and Productivity}

Kenikir (Cosmos caudatus Kunth) is
mainly intercropped with vegetables commercially-cultivated worldwide (hereafter designated 'common vegetables') such as leek, cabbage and lettuce at high altitudes, and with sweet corn and long beans at low altitudes. Many farmers plant kenikir as border plants along planting beds of common vegetables because they believe that it can reduce soil diseases and pests such as nematode. Van den Bergh (1994a) considered that kenikir improve soil structure and suppress some weeds, including Imperata cylindrica. Only few farmers cultivate kenikir on their farms as main crop. They dedicated 200 to $2500 \mathrm{~m}^{2}$ specially for growing the kenikir. Among research sites, the largest farm $\left(2500 \mathrm{~m}^{2}\right)$ is found in a farmer in Pasir Sarongge (Cianjur District), where a local variety of kenikir is grown as a commercial crop. In commercial kenikir farms, seeds are sown in beds and raised for one to two weeks. Then seedlings are transplanted in a square pattern, e.g., $25 \mathrm{~cm}$ $\times 25 \mathrm{~cm}$. Goat manures are applied at planting, while mineral fertilizers are rarely applied to kenikir. Some farmers apply nitrogen (urea $46 \% \mathrm{~N}$ ) at a rate of $1-2 \mathrm{~g}$ per plant along with goat manure. When inflorescences emerge six to eight weeks after planting, edible parts of kenikir, i.e., leaves, young shoots and inflorescences, are harvested for the first time. Farmers usually continue to harvest new offshoots until six months after planting, although some farmers replant new seedlings after only one harvest. According to Van den Bergh (1994a), harvesting could be continued for two to three years after planting, but most farmers stop harvesting within six months after planting, possibly because plants are infested with diseases in dry season. Harvest frequency varies among research sites, i.e., once every week in Sukaharja - Ciapus (Bogor), once every month in Pasir Sarongge (Cianjur) and 5-6 times per month in Ciampea (Bogor). Average productivity is highly variable among research sites, i.e., 458, 298 and $1214 \mathrm{~kg} \mathrm{ha}^{-1}$ per harvest in Sukaharja - Ciapus, Pasir Sarongge and Ciampea, respectively (Table 1). In Leuwiliang Subdistrict (close to Ciampea village), extension program for the 
enhancement of indigenous vegetable production had been conducted by Bogor Agricultural University under the Sustainable Agriculture and Natural Resource Management (SANREM) Project in early 2000s. According farmers, they follow techniques applied by Leuwiliang farmers resulting in high yield of kenikir in Ciampea site.

Genjer (Limnocharis flava (L.) Buchenau) was introduced into Southeast Asia from tropical and subtropical America, and naturalized in Indonesia, Malaysia and Thailand (van den Bergh, 1994b). Genjer grows naturally in lowlands such as swampy land, paddy field, riverbank and fish ponds with water level less than $20 \mathrm{~cm}$. Genjer plants cannot grow in ponds of which water depth is over $30-40 \mathrm{~cm}$. Genjer plants are propagated either by seeds or vegetative through suckers. Edible parts of genjer are the peduncles, petioles, leaf blades and the unopened inflorescences. Farmers harvest wild genjer plants or semi-cultivated genjer plants in fields
(50, 100 and $12 \mathrm{~m}^{2}$ on average in Citalahab Tasikmalaya, Pasir Sarongge - Cianjur and Ciampea - Bogor, respectively). In fields with genjer plants, farmers harvest leaves and inflorescence regularly without any fertilizer application. When medium sized suckers (ca. 12 to $15 \mathrm{~cm}$ in height) are transplanted, first harvest is possible 5 weeks after transplanting ( 2 to 3 leaf stage with an inflorescence). Interviews with farmers indicate that harvesting frequency varies dependent on location and soil fertility. Harvest is conducted once a week in Pasir Sarongge - Cianjur, and twice a week in Ciampea - Bogor and Citalahab - Tasikmalaya. Generally, about 0.2$0.3 \mathrm{~kg} \mathrm{~m}^{-2}$ of genjer is collected per week. In Pasir Sarongge, many farmers keep genjer plants along the edge of paddy fields or water convolvulus (Ipomea aquatica) fields, whereas farmers in Ciampea and Citalahab collect naturally-grown genjer. Therefore, productivity of genjer is higher in Pasir Sarongge - Cianjur than in other two sites (Table 1).

Table 1. Agronomic characters of four indigenous vegetables in West Java based on individual plant measurement $(\mathrm{n}=10)$

\begin{tabular}{|c|c|c|c|c|c|c|c|c|c|c|c|c|}
\hline \multirow{2}{*}{ Characters } & \multicolumn{3}{|c|}{ Kenikir } & \multicolumn{3}{|c|}{ Genjer $^{\mathrm{Z}}$} & \multicolumn{3}{|c|}{ Poh-pohan } & \multicolumn{3}{|c|}{ Leunca } \\
\hline & I & II & III & II & III & IV & I & III & IV & I & II & III \\
\hline $\begin{array}{l}\text { Plant density } \\
\text { (plants } \mathrm{m}^{-2} \text { ) }\end{array}$ & 16 & 16 & 16 & 16 & 16 & 16 & 16 & 16 & 4 & 4 & 2 & 4 \\
\hline $\begin{array}{l}\text { First harvest } \\
\left(\text { WAP }^{\mathrm{y}}\right)\end{array}$ & 6 & 6 & 8 & 5 & 6 & 5 & 6 & 6 & 6 & 6 & 6 & 7 \\
\hline $\begin{array}{l}\text { Number of } \\
\text { harvest per } \\
\text { month }\end{array}$ & 4 & $5-6$ & 1 & 8 & 4 & 8 & 2 & 4 & 4 & 6 & 7 & 4 \\
\hline $\begin{array}{l}\text { Last harvest } \\
\text { (WAP) }\end{array}$ & 24 & 24 & 28 & 24 & 24 & 24 & 24 & 24 & 24 & 24 & 26 & 24 \\
\hline $\begin{array}{l}\text { Yield ( } \mathrm{kg} \mathrm{ha}^{-1} \\
\text { per harvest) }\end{array}$ & 458 & 1214 & 298 & 1939 & 8924 & 2459 & 2106 & 2199 & 1427 & 350 & 1249 & 855 \\
\hline $\begin{array}{l}\text { Total yield (ton } \\
\text { ha }^{-1} \text { per season) }\end{array}$ & 11.0 & 29.1 & 7.1 & 23.2 & 53.5 & 29.5 & 25.3 & 26.4 & 17.1 & 8.4 & 29.9 & 20.5 \\
\hline $\begin{array}{l}\text { Presence of } \\
\text { Oxalate } \\
\text { crystals }\end{array}$ & + & + & + & + & + & + & - & - & - & - & - & - \\
\hline
\end{tabular}

${ }^{\mathrm{Z}}$ Experimental plot was set up for genjer and poh-pohan in Tasikmalaya (Tasik in this table), not Ciapus (Bogor) and Ciampea (Bogor), respectively; ${ }^{\mathrm{Y}} \mathrm{WAP}$-weeks after planting; ${ }^{\mathrm{X}}$ Oxalate crystals were observed by squeezing leaf/fruit and observed under microscope of 400x magnification; + indicates that druses of oxalate crystals are visible and "_-"druses are not visible. I= Ciapus (Bogor), II= Ciampea (Bogor), III= Cianjur, IV= Tasikmalaya. 
Poh-pohan (Pilea melastomoides (Poir.) Bl.) is a succulent plant. It grows naturally in moist and shady, but well drained conditions such as areas beside gutters, fountains and fish ponds. Farmers harvest wild poh-pohan, but also cultivate poh-pohan in upland fields. In humid areas poh-pohan plants are less susceptible to diseases than plants grown in dry areas. It is probable that low light intensity in moist areas (ca 70-80\% of full sunshine) is suitable for poh-pohan growth because stalk and petiole color becomes purplish under full sunshine. Ekawati et al. (2010) stated that productivity of poh-pohan growing under up to e.g. $75 \%$ of shading is five times larger than those under full sunshine. Our farmer respondents believe that poh-pohan growing in shady areas develop more juicy and crispy petioles than those growing under full sunshine. Most farmers cultivate poh-pohan on their 100-200 $\mathrm{m}^{2}$ fields. The largest intensive farm is found in Bogor (Sukaharja - Ciapus), where poh-pohan plants are intercropped with fruit and coconut trees on about $2500 \mathrm{~m}^{2}$ field.

Poh-pohan are usually propagated by stem cutting with 2-3 nodes, and rarely propagated by seeds. As Mahyar (1994) stated, poh-pohan can be propagated by seeds, but small seeds like poh-pohan need extra attention at sowing. It takes 3 to 4 weeks for cuttings to attain the size for transplanting, e.g., 10 to $15 \mathrm{~cm}$. Planting density varies among study sites ranging from $25 \mathrm{~cm} \times 25 \mathrm{~cm}$ to $50 \mathrm{~cm} \times 50 \mathrm{~cm}$. The first harvest, i.e., pinching 4-5 leaves at the top of shoot, is conducted 6 weeks after transplanting, thereafter, 4 to 5 leaves are pinched every two weeks in Bogor (Sukaharja - Ciapus) and weekly in Pasir Sarongge - Cianjur and Citalahab - Tasikmalaya. After the first harvest, farmers apply fertilizers to stimulate new shoot. Total harvest per season was $25.3 \mathrm{t} \mathrm{ha}^{-1}, 26.4 \mathrm{t} \mathrm{ha}^{-1}$ and $17.1 \mathrm{t} \mathrm{ha}^{-1}$ in Bogor (Sukaharja - Ciapus), Cianjur (Pasir Sarongge) and Tasikmalaya (Citalahab), respectively (Table 1).

Leunca (Solanum americanum Miller) is a perennial crop which probably originates in South America (Siemonsma and Jansen, 1994). It is cultivated together with cash crops on farms and home gardens or grows wild as a weed. Plants are propagated by seed or stem cutting. Seeds were collected from mature, dark purple fruits. Seedlings are transplanted 3 weeks after sowing, while $15-20 \mathrm{~cm}$ stems are planted directly into soil for stem cutting. Plants were planted in a square pattern, i.e., 50 $\mathrm{cm} \times 50 \mathrm{~cm}$ in Sukaharja - Ciapus and Pasir Sarongge, and $75 \mathrm{~cm} \times 75 \mathrm{~cm}$ in Ciampea. Inflorescences are harvested when fruits become dark green to tinny light purple in color. Subsequent harvest is carried out four to six times a month dependent on research sites. In intensive cultivation, which is carried out by some farmers in Bogor (Ciampea), nitrogen fertilizer is applied at a rate of $2-3 \mathrm{~g}$ per plant to maintain high productivity. According to the interviewees, there was variation in total yield of leunca fruits among locations. Harvest of leunca usually last 6 months after planting in rainy season and the plant die, but harvest extends on month in Bogor (Ciampea) up to 7 months after planting because available of irrigation. High yield of leunca was obtained in Ciampea (1 $249 \mathrm{~kg} \mathrm{ha}^{-1}$ per harvest), followed by Pasir Sarongge (855 kg ha ${ }^{-1}$ per harvest) and Ciapus village of Bogor $(350 \mathrm{~kg}$ ha $^{-1}$ per harvest) (Table 1). According Putriantari and Santosa (2014) fruit production of leunca increases by increasing level of $\mathrm{N}$ application, application at rate of $180 \mathrm{~kg} \mathrm{~N} \mathrm{ha}^{-1}$ obtains more than 18 ton fruit $\mathrm{ha}^{-1}$ during growing season equal to $2000 \mathrm{~kg} \mathrm{ha}^{-1}$ per harvest. Therefore, low productivity of leunca of farmers in this study could be ascertained from low $\mathrm{N}$ application.

\section{Indigenous Vegetables Market}

In Bogor, there are 14 vegetable retail outlets, i.e., four large traditional vegetable markets (Pasar Bogor, Pasar Anyar, Pasar Empang, and Pasar Yasmin) and nine supermarkets (4 Giant and 5 Matahari stores). In these retail outlets, regardless of traditional markets and supermarkets, 14 to 40 species (28 on average) of vegetables are sold every day, and 25 to $58 \%$ of species are local vegetables. Some local vegetables including indigenous vegetables are young fruits, male flowers and young leaves of papaya (Carica papaya), antanan (centella leaves, Centella asiatica), batang talas (taro stolon, Colocasia esculenta), daun gedi (edible hibiscus leaves, Hibiscus manihot), daun jambu monyet (young cashew leaves, Anacardium occidentale), daun katuk (leaves of Sauropus androgynus), daun kacang buncis (green beans leaves, Phaseolus vulgaris), daun kacang tanah (peanut leaves, 
Arachis hypogaea), daun labu parang (winter squash leaves, Cucurbita maxima), daun labu siam (chayote leaves, Sechium edule), daun mangkokan (shield aralia leaves, Polyscias scutellaria), daun melinjo (gnetum leaves, Gnetum gnemon), daun singkong (cassava leaves, Manihot esculenta), daun ubi jalar (sweet potato leaves, Ipomoea batatas), genjer leaves and inflorescence, jantung pisang (inflorescence of banana, Musa paradisiaca), kemangi (basil leaves, Ocimum americanum), kenikir leaves, leunca fruits, poh-pohan leaves, pucuk kemang (young leaves of wild mango, Mangifera kamanga), selada air (watercress, Nasturtium officinale), terong lalap (small green fruits of eggplant, Solanum melongena), and triwis (sprout of cabbage offshoot, Brassica olerace). Mushroom was not included in this survey.

Among more than 200 retailers in Pasar Anyar market, seven retailers sell indigenous vegetables including kenikir, genjer, pohpohan and leunca. On average, a retailer sells $10 \mathrm{~kg}$ of kenikir, $40 \mathrm{~kg}$ of genjer, $30 \mathrm{~kg}$ of poh-pohan, $50 \mathrm{~kg}$ of leunca fruits every day. Leaves of kenikir, genjer and poh-pohan are usually split into lots weighing 100 to $200 \mathrm{~g}$ by wholesalers, and sold at a price ranging from 500 to 2000 rupiah per $100 \mathrm{~g}$ (ca. 0.05-0.2 USD $\mathrm{kg}^{-1}$ ). A middleman distributes the vegetables to 3-5 wholesalers. There are three large wholesalers in the Pasar Bogor who take a contract with middlemen and receive indigenous vegetables from them. Most retailers in the Pasar Anyar, source indigenous vegetables from large wholesalers in Pasar Bogor, but some retailers source the vegetables directly from middlemen in Ciampea and Leuwiliang Subdistricts (Bogor). However, there are variations in the distribution channels among cities. For example, in Citalahab - Tasikmalaya, farmers in remote areas sell indigenous and common vegetables to peddlers (pedagang keliling) and consumers directly as well as middlemen, whereas farmers near markets sell it to middlemen, retailers, and wholesalers.

On average, it took about 20 hours from a farm to a consumer. A middleman in Ciampea buys $3 \mathrm{~kg}$ of kenikir, $20 \mathrm{~kg}$ of genjer, $20 \mathrm{~kg}$ of poh-pohan and $40 \mathrm{~kg}$ of leunca, everyday, while a middleman in Pasir Sarongge buys $80 \mathrm{~kg}$ of kenikir, $50 \mathrm{~kg}$ of genjer, $100 \mathrm{~kg}$ of poh-pohan and $40 \mathrm{~kg}$ of leunca. Retailers stated that indigenous vegetables deteriorate faster than common vegetables, so they usually spray water frequently to keep vegetables fresh longer. It is common to place vegetables in a plastic bag with a capacity of 20 liter during transportation. Long distance transportation is usually carried out in the evening or during the night to prevent water loss via transpiration at high temperatures. Especially, kenikir and poh-pohan leaves are easily deteriorated as compared to genjer leaves and leunca fruits. Genjer is more susceptible to physical impact damage than other vegetables, thus careful handling is necessary.

Contribution of indigenous vegetables to farmers' income is the largest in Bogor (pooled Ciampea and Ciapus), followed by Pasir Sarongge - Cianjur and Citalahab Tasikmalaya sites, i.e., $18.9 \%, 3.8 \%$ and $1.7 \%$, respectively. Nevertheless, sales amount of indigenous vegetables is the largest in Tasikmalaya, followed by Cianjur and Bogor sites (Fig. 1 A), indicating that a large contribution of indigenous vegetables to farmers' income is due to high price in Bogor.

\section{Consumer Preferences}

Indigenous vegetables are generally eaten raw (kenikir and poh-pohan leaves and leunca fruits), slightly boiled (kenikir leaves) or boiled gently (genjer leaves and leunca fruits). About $78 \%$ of consumers prefers slightly boiled vegetables which are prepared as gado-gado (Indonesian salad served with peanut sauce), while others prefer to eat raw as salad, particularly for kenikir leaves and leunca fruits. As salad, kenikir and poh-pohan leaves are usually eaten with sambal (chili paste). Leunca fruits are sometimes stir-fried with chili and oncom (a kind of fermented soybean cake, alike tempe). In Central Java Province, there are two varieties of leunca, i.e., small leunca (ranti in Javanese) and large leunca (ranti kebo), but most farmers in West Java are familiar only with large leunca. Sizes of fruits and leaves of small leunca are about half of large leunca. Javanese people consume leaves of small and large leunca, while Sundanese people consume fruits of large leunca. Large leunca leaves is bitterer than those of small leunca, according to Javanese. Mature fruits of small leunca taste sweet, so 
children usually consume as sweet in Central Java.

Preferences for indigenous vegetables are different among households and among family members. In general, younger families (married for less than 5 years) consume less indigenous vegetables than older ones (married for longer than 10 years). Young people believe that indigenous vegetables have harmful effect on reproduction system; therefore, they prefer common vegetables. Furthermore, young people's distaste for indigenous vegetables is related to their taste and odor. Bitter taste is dominant for leunca fruits and genjer inflorescences although taste is very soft for genjer leaves. On the contrary, more than $54 \%$ of households with middle- aged and elderly wives prefer indigenous vegetables, with less than $17 \%$ in distaste.

The amount of indigenous vegetables consumed per household per day is dependent on the relative availability of indigenous vegetables and common vegetables such as amaranth, cabbage, carrot, kankoong, lettuce, and pakchoi. Daily expenditure for vegetables is $19.8,18.8$ and 12.5 thousand rupiah for households in Bogor, Pasir Sarongge - Cianjur and Citalahab - Tasikmalaya sites, respectively; those accounted for $35.4 \%, 13.3 \%$ and $20 \%$ of total vegetable expenditure. Average daily demand for common vegetables in study sites ranged from 0.7 to $1.5 \mathrm{~kg}$ per household; daily purchases of vegetables amount to10 to 16.3 thousand rupiah (Fig. 1B).

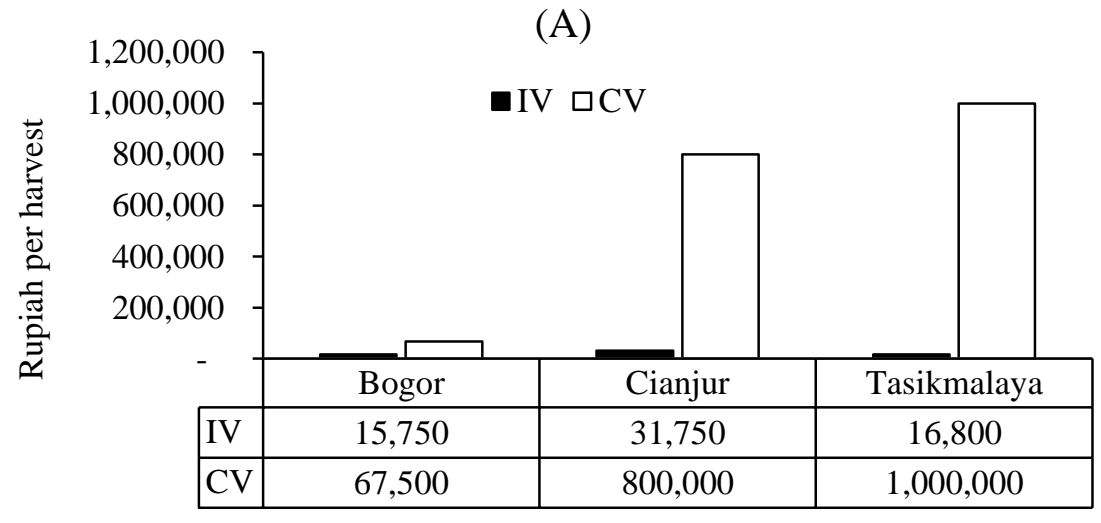

(B)

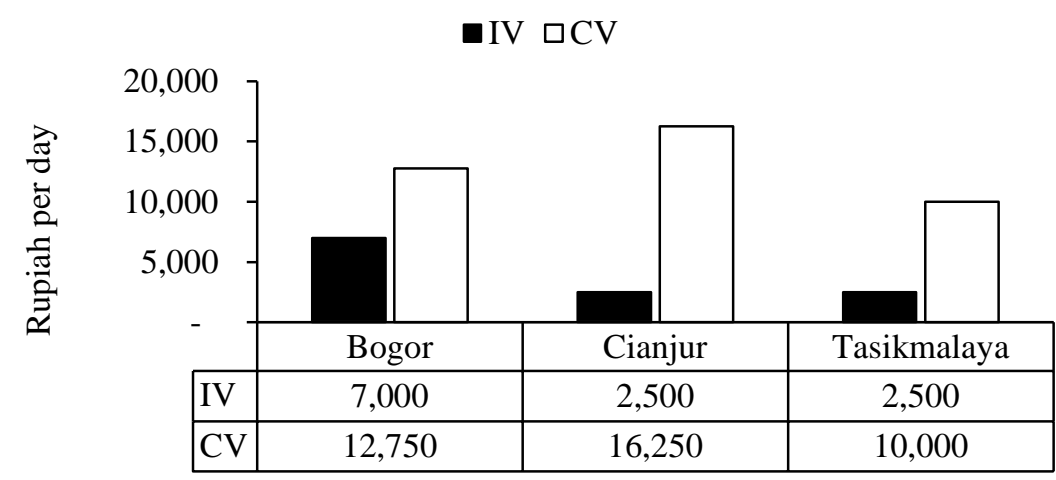

Figure 1. Average farmers' income from the sales of indigenous and common vegetables (A) and average daily expenses of a household for indigenous and common vegetables (B) in Bogor, Cianjur (Pasir Sarongge) and Tasikmalaya (Citalahab). In Bogor, data at Ciapus and Ciampea research sites were pooled. Rp 10,000 equal to 1 USD. IV $=$ indigenous vegetables; $\mathrm{CV}=$ common vegetables. 
Most respondents rarely use kenikir and genjer together with common vegetables in cooking, but they sometimes use leunca together with common vegetables. When data from all research sites were pooled, $90 \%$ of household buy less than $1 \mathrm{~kg}$ of indigenous vegetables at a time. Only less than $1.5 \%$ of respondents buy more than $1 \mathrm{~kg}$ which mainly consists of genjer and kenikir. For poh-pohan and leunca, they frequently buy about $0.2 \mathrm{~kg}$ and $0.1 \mathrm{~kg}$, respectively. Certainly, the purchase volume of indigenous vegetables is negatively related with the purchase volume of common vegetables; when they buy relatively large amount of indigenous vegetables, they buy a small amount of common vegetables, and vice versa (Fig.2).

On average two thirds of the consumers ate indigenous vegetables not so often; only $10.5 \%, 7.8 \%$ and $5.3 \%$ of consumers ate indigenous vegetables daily, more than once a week and once a week, respectively. It appears that less frequent eating of indigenous vegetables is not related to their low availability because only about $5 \%$ of consumers replied that they could not find indigenous vegetables when they need. More than $50 \%$ of consumers acknowledged that kenikir and genjer were easily obtainable in markets in all research sites. About $70 \%$ of consumers could buy poh-pohan from nearby retailers, while only $15 \%$ had some difficulties to obtain it. Regarding purchase route, $45 \%$, $36 \%$ and $15 \%$ of consumers obtained from grocery stores (warung), nearby markets and peddlers (pedagang keliling), respectively. About 5\% of consumers usually placed an order for indigenous vegetables with retailers in advance. According to retailers, sales amount of indigenous vegetables is lower than that of common vegetables (ca 30\%) in medium to high-income areas. The retailers argued that indigenous vegetables are probably vegetables for low-income class.

It is likely that low price provides motive for buying indigenous vegetables. More than $65 \%$ of consumers replied that indigenous vegetables could be purchased at a lower price as compared with common vegetables such as amaranth, carrot, cucumber, cabbage, lettuce, pakcoy, etc. About 10-30\% of consumers replied that indigenous vegetables were considered medium-priced. However, most consumers who buy it in supermarkets stated that indigenous vegetables are as expensive as common vegetables.

It is considered that indigenous vegetables have benefits on health, and this notion stimulating indigenous vegetable consumption. However, high-income class (monthly income > 5 million rupiah) prefers common vegetables to indigenous vegetables because they consider that the indigenous are inferior in cleanness and healthiness.

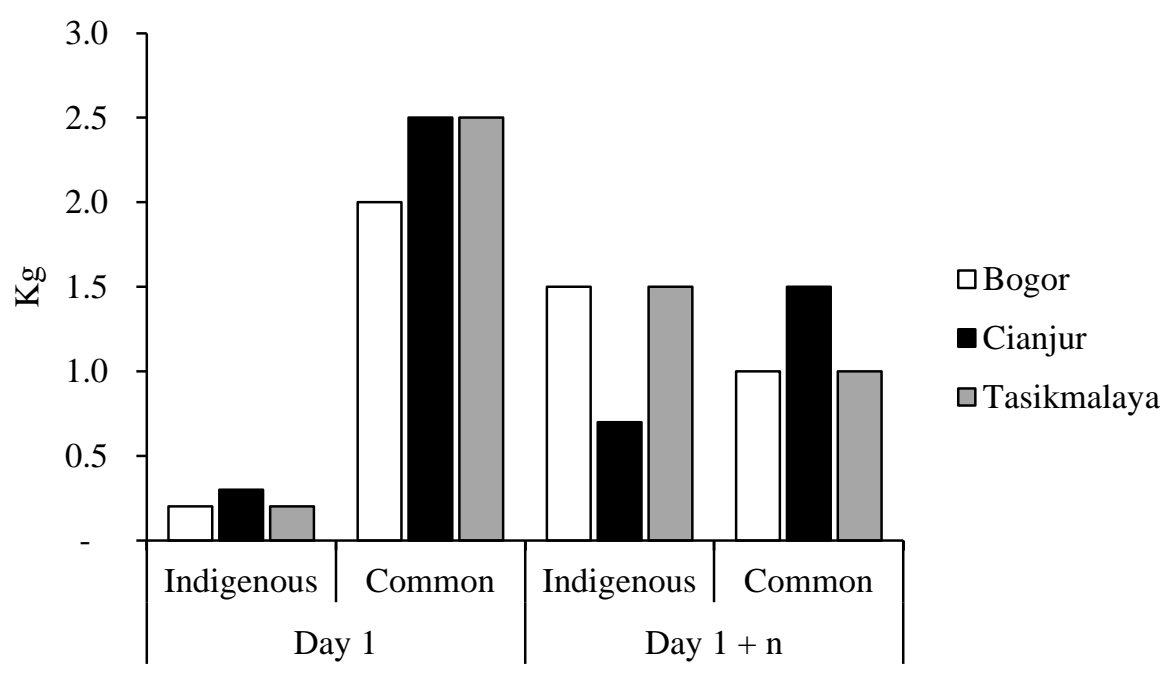

Figure 2. Average amount $(\mathrm{kg})$ of indigenous and common vegetables purchased by households in Bogor (Ciampea and Sukaharja - Ciapus), Cianjur (Pasir Sarongge) and Tasikmalaya (Citalahab) on two different days (Day 1 and Day $1+n$ ), based on interview. 
In fact, about $10 \%$ of consumers complained digestion problems after consuming indigenous vegetables. Health complaint due to the ingestion of indigenous vegetables, e.g., headache and disorder of uric acid metabolism, was reported by respondents, although no specific vegetables were identified. However, 50\% of consumers recognized health improvement by ingestion of indigenous vegetables, while $20 \%$ recognized no discernible effects. Mohamed $e t$ al. (2012) reported that consumption of Cosmos caudatus at $500 \mathrm{mg} \mathrm{kg}^{-1}$ body weight has the potential to act as the therapeutic agent to restore bone damage in postmenopausal. In Sri Lanka, cooked salads of genjer are eaten as a cure for rheumatism (Haynes and Les, 2004). Most consumers pointed out that they did not sense intensely unpleasant smell in toilets if they ate kenikir and poh-pohan. It is probable that high content of flavoring substances in indigenous vegetables get rid of bad smell such as for kenikir and poh-pohan.

Consumers usually determined which types of vegetables to buy according to the following criteria, e.g., cooking experience, easiness of cooking, taste and appearance. Among criteria for choosing, easiness of cooking was the most important criterion; more than $60 \%$ of consumers choose a vegetable according to this criterion although less than $30 \%$ of consumers (mainly young people) in both rural and urban areas found indigenous vegetables difficult to cook. As of other criteria, $35 \%$ and $25 \%$ of consumers pointed out strong flavor and the appearance (color and freshness), respectively. On the other hand, only $15 \%$ of consumers determined which kinds of vegetables to buy according to its familiarity. Most young women never eat leunca fruits and genjer leaves because they believe leunca fruits have adverse effect on fertility and genjer leaves are non-nutritious and dirty. In most Southeast Asian countries, genjer is treated as a noxious weed in paddy field (Ranawakage et al., 2014).

\section{CONCLUSION}

Indigenous vegetables have crucial roles in enriching the dietary life of people and generating farmers' income in West Java. Farmers also produced indigenous vegetables as a way to ensure self-sufficiency of vegetables. Manure and chemical fertilizers are rarely applied to indigenous vegetables. From economic point of view, the vegetables were traded locally through various channels of distribution, e.g., farm-gate sales and market sales by local vegetables retailers and supermarkets. Although the sales amount of indigenous vegetables are still limited, these vegetables are promising with an increase in the number of street restaurants where indigenous vegetables are commonly used. It is probable that experience of eating indigenous vegetables at street restaurants have accustomed young people to the taste of indigenous vegetables, leading to an increase in the consumption of indigenous vegetables by younger generation.

\section{REFERENCES}

Andarwulan, N., R. Batari, D.A. Sandrasari, B. Bolling, H. Wijaya. 2010. Flavonoid content and antioxidant activity of vegetables from Indonesia. Food Chem. 121(4): 1231-1235.

Ekawati, R., A.D. Susila, J.G. Kartika. 2010. The effect of shade on growth and productivity of several indigenous vegetable. J. Hort. Indonesia. 1(1):46-52.

Engle, L.M., F.C. Faustino. 2007. Conserving the indigenous vegetable germplasm of Southeast Asia. Acta Hort. 752: 55-60.

Fuzzati, N., Sutarjadi, W. Dyatmiko, A. Rahman, K. Hostettmann. 1995. Phenylpropane derivates from roots of Cosmos caudatus. Phytochemistry. 39: 409-412.

Hassan, S.A., S. Mijin, U.K. Yusoff, P. Ding, P.E.M. Wahab. 2012. Nitrate, ascorbic acid, mineral and antioxidant activities of Cosmos caudatus in response to organic and mineral-based fertilizer rates. Molecules. 17: 7843-7853. DOI:10.3390/17077843.

Haynes, R.R., D.H. Les. 2004. Alismatales (water plantains). Nat. Encyclopedia Life Sci. 1-4. DOI: 10.1038/npg.els. 0003702. 
Kusmana, Suryadi. 2004. Mengenal Sayuran Indijenes. BALITSA. p. 27. Bandung.

Mahyar, U.W. 1994. Pilea lindley. In J.S. Siemonsma, K. Piluek (eds.). PROSEA 8. Vegetables. Bogor. Indonesia. p. 224226.

Mohamed, N., S.G.S. Khee, A.N. Shuid, N. Muhammad, F. Suhaimi, F. Othman, A.S. Babji, I.N. Soelaiman. 2012. The effects of Cosmos caudatus on structural bone histomorphometry in ovariectomized rats. Evidence-Based Complementary Alternat. Med. 2012:1-6. DOI:10.1155/ 2012/817814.

Putrasamedja, S. 2003. Eksplorasi dan koleksi sayuran indigenous di kabupaten Karawang. Buletin Plasma Nutfah. 11:16-20.

Putriantari, M., E. Santosa. 2014. Growth and alkaloids levels of leunca (Solanum americanum Miller.) of different nitrogen application. J. Hort. Indonesia 5(3):175-182.

Ranawakage, V.P., K.C. Ellawala, G.G.T. Chaminda. 2014. Root and leaf extract allelopathic effect of Limnocharis flava on seed germination and growth of rice. World J. Agric. Sci. 10 (1): 14-17. DOI: 10.5829/idosi.wjas.2014.10.1.1756.

Siemonsma, J.S., P.C.M. Jansen. 1994 Solanum americanum Merrill. In J.S. Siemonsma, K. Piluek (eds.). PROSEA 8. Vegetables. Bogor. Indonesia. pp. 252-255.

Van den Bergh, M.H. 1994a. Cosmos caudatus Kunth. In J.S. Siemonsma, K. Piluek (Eds.). PROSEA 8. Vegetables. Bogor. Indonesia. pp. 152-153.

Van den Bergh, M.H. 1994b. Limnocharis flava (L.) Buchenau. In J.S. Siemonsma, K. Piluek (Eds.). PROSEA 8. Vegetables. Bogor. Indonesia. pp. 192194. 